\title{
Developing autonomy through portfolios and networks in CLIL lectures
}

\author{
El desarrollo de la autonomía mediante el uso de portafolios y redes \\ en conferencias de AICLE
}

\author{
John Lindsay ADAMSON \\ University of Niigata Prefecture
}

(Niigata, Japan)

\begin{abstract}
This study has explored the use of portfolios and of awareness-raising of literacy networks in a CLIL lecture preparation class for first-year undergraduates in a Japanese university. It is argued that CLIL-related literature has a paucity of practical studies investigating these two elements essential to autonomy-building, particularly for students who have been previously mostly exposed to teacher-centered modes of instruction. Questionnaires asking students their perceptions of portfolio use and self-study were gathered over three years and were coupled with a one year small-scale data set of student-drawn 'literacy maps' exploring who and what materials students had consulted to produce a final lecture-related report. Findings revealed increased awareness of the importance of portfolio and selfstudy and even their cross-fertilization over to other classes across the language and content curricula; however, some reticence was evident regarding self-scoring in self-study mode, showing that the transition from traditional teachercentredness at high school had not yet been overcome. Also, of importance was the initially extensive use of self-access center advisors which, when withdrawn, may have negatively impacted students' literacy networks. Implications to be drawn from this study lie primarily in the expanded use of portfolios and increased awareness-raising of student networks as important means towards the development of autonomous study skills and literacy. Questions do, however, remain as to the extent that this approach actually mirrors English-medium instruction in content classes at the university.
\end{abstract}

Key Words: Portfolios; literacy networks; CLIL; lectures.

\section{Resumen}

Este trabajo ha explorado el uso de portafolios y de redes de sensibilización hacia la alfabetización, en una clase de preparación de clases magistrales de AICLE para estudiantes de primer año de pregrado en una universidad japonesa. Se argumenta que la literatura relacionada con AICLE carece de estudios prácticos que investiguen sobre estos dos elementos que son esenciales para el desarrollo de la autonomía, particularmente para estudiantes para quienes han sido expuestos, ante todo, a modos de enseñanza centrados en el profesor. Durante tres años se aplicaron cuestionarios a los estudiantes con respecto a sus percepciones sobre el uso de portafolios que se conjugaron con un conjunto pequeño de datos obtenidos durante un año, sobre "mapas de alfabetización" producidos por los estudiantes, explorando a quiénes y qué materiales consultaron los estudiantes para producir un reporte final relacionado con la clase magistral. Los hallazgos mostraron una aumento en la sensibilización acerca de la importancia de los portafolios y el autoaprendizaje e incluso su transferencia a otras asignaturas; sin embargo, fue evidente alguna reticencia en cuanto a la auto calificación en el modo de auto-aprendizaje, que muestra cómo no ha podido ser superada la transición desde el modelo tradicional centrado en el maestro que se utiliza en la secundaria. También fue de importancia que al inicio se acudió extensamente a los asesores del centro de auto-acceso. Cuando fueron eliminados, esto pudo haber afectado de manera negativa las redes de alfabetismo de los estudiantes. Las implicaciones que pueden ser derivadas de este estudio están relacionadas fundamentalmente con el aumento en el uso de los portafolios y la sensibilización hacia el uso de redes estudiantiles como elementos importantes para el desarrollo de habilidades para el estudio autónomo y la alfabetización. No obstante, persisten las preguntas en cuanto a si este enfoque realmente refleja la forma en la cual se da la enseñanza en inglés en diversas asignaturas en la universidad.

Palabras Claves: portafolios; redes de alfabetismo; AICLE; clases magistrales.

Adamson, J. (2014). Developing autonomy through portfolios and networks in CLIL lectures. Latin American Journal of Content and Language Integrated Learning, 7(1), 21-39. 


\section{INTRODUCTION}

This study explores the use of portfolios and awareness-raising of literacy networks as a means towards the nurturing of autonomous modes of study in an English language lecture course in a Japanese university. The compulsory course for first year undergraduate students adopts a Content and Language Integrated Learning (CLIL) approach in that it prepares students for their current and future demands of English-medium instruction (EMI). In this sense, the lecture course syllabus aims to improve language proficiency for Japanese students, whilst exposing them to content materials and pedagogy from their content studies. Important to the focus of this study is the supplementary course objective of developing autonomous study skills which can be put to use across language and content studies. Specifically, the use of student-compiled portfolios and awareness of how students can access a wider network of people and materials to achieve the lecture course outcomes are seen as the key elements towards the acquisition of these cross-curricular study skills. In this sense, the perspective taken on autonomy is that of how learners take control of learning management (Benson, 2001) after goals have been set, seen by Littlewood (1999, p. 75) as "reactive" autonomy.

I will give a brief background to the educational context underpinning the study, before reviewing the literature in the fields of autonomy, CLIL, portfolios and networking. The methodology by which data was gathered will then be outlined, after which findings will be presented. A discussion linking key findings to the literature will be given, followed by conclusions and implications for further practice.

\section{Background}

The study takes place in a new Japanese prefectural university established in 2009. Previous to the granting of university status, the institution had been a two-year college where English was taken as a course of study but not linked to other content studies. Once opened, the university set EMI as a goal for undergraduate studies in International Relations and Regional Development. To support this EMI focus, English curriculum objectives shifted from English as a Foreign Language (EFL) to English for Academic Purposes (EAP). This mirrors a growing trend in Japanese tertiary education with over 190 universities adopting 
EMI in 2008 (Miichi, 2010) and recently more universities selected by the government to create special CLIL curricula from 2012 (MEXT, n.d.).

The first-year lecture class in question is one of a range of EAP compulsory classes at the institution taken by approximately 180 students once a week over a year. Its CLIL approach combines content and language aims by adopting materials and methods of instruction from selected compulsory content classes. On the university curriculum, the class itself is identified as "language-led" (Clegg, 2003, p. 89) as it is part of the EAP curriculum and is taught by a language specialist. To further support the students' abilities to study independently, monitor their own progress, and manage their own learning, the class makes use of portfolios of teacher hand-outs and student course work. Secondly, a smallscale study into student use of people and materials useful to their lecture class studies (other than the lecture teacher and class hand-outs) has been conducted to gauge their awareness of their own "literacy networks" (Lillis \& Curry, 2010, p. $65)$.

The lecture class itself is multimodal in nature, combining lecture listening skills with reading, discussions, and report writing. To improve content and language knowledge and skills, there is a sustained focus over several lessons on the content curriculum-related themes of economics, environment, health, and culture. Evaluation is based on portfolio management, homework writing tasks, self-study (through re-listening to lectures, note-taking of other EMI special lectures and online academic vocabulary), and importantly, a final written report. These forms of evaluation are chosen to represent and mirror both language and content assessment modes currently used at the university.

During the lecture course, students are encouraged regularly to reflect upon how they study effectively on the course by completing a questionnaire asking them about their perceptions of the course and their own study progress twice an academic year (distributed from 2011 to the present, early in the first semester, and at the end of the final, second semester). Perceptions of the course's approach have been reported in Adamson and Coulson (forthcoming); however, a more in-depth analysis of the use of portfolios and the students' networking skills is considered useful at this point in the history of the course, so responses from the questionnaire focusing on portfolio use which were covered previously only in brief (Adamson \& Coulson, forthcoming) can now be expanded upon and combined with findings from studies into networking. This 
analysis is considered as highly informative to the lecture course lecturers as the Japanese students under investigation are potentially unfamiliar EMI and autonomous modes of study expected of them at university as they have previously been exposed to mostly test-focused and teacher-centered English language instruction at high school (Okano \& Tsuchiya, 1999).

Of final importance in the support of this course's aim of promoting autonomy among students is the existence in the new university of a Self Access Learning Center (SALC) staffed by language learning advisors (termed as 'mentors' in this context) and resources relevant to the content of the lecture class themes. With the large number of students in the class, SALC mentors are engaged in advising students about portfolio management, access to relevant resources, and language-related issues, particularly report writing. As the SALC's objective within the growing university is to nurture autonomy, the role of the center and its mentors are potentially of significance for this study's theme.

\section{Aims of the study}

The aims of the study are fundamentally intrinsic in nature, in that they seek to inform the lecturers responsible for the lecture course syllabus design about the effectiveness of the attempts to develop autonomy in this distinct CLIL setting. The specific research question is: What role do portfolios and networking play towards the development of autonomy in this CLIL approach to lecture preparation?

\section{Literature review}

The literature review will focus on autonomy, CLIL, portfolio use, and networking to develop academic literacy, particularly in the Japanese tertiary context of this study.

Turning firstly to issues of learner autonomy in Asian educational contexts, it has been argued that autonomy is frequently taken as a pedagogical concept within which western values are embedded and therefore incongruent to Asian educational values (Sinclair, 1997; Kubota, 2002; Holliday, 2003). Asian learners themselves are commonly stereotyped as passive and ineffective language learners who require "corrective training" (Holliday, 2003, p. 112). In response, Littlewood (2000) and Benson, Chik and Lim (2003) challenge this stereotype by noting the possibly distinct nature of Asian learners' "autonomous interdependence" (p. 23), one which favors collaborative modes of learning 
(Biggs, 1994). Important to this preference towards a more socially mediated form of autonomy is the "pedagogical dialogue" (Little, 2000, p. 3), not simply between students and teachers, but also among students themselves, and additionally with a variety of accessible "brokers" (Lillis \& Curry, 2010, p.13). These are people accessible to students who can provide advice on learning and resources to enhance literacy, potentially in tertiary contexts with SALCs in the form of learning advisors, or 'mentors', who are positioned as close to students and informed of their needs, yet distinct from traditional teachers (MozzonMcPherson, 2001). The shift from the teacher-dependence of language learning in Japanese high schools to learner self-direction at the tertiary level is clearly cognitively challenging and requires the guidance by teachers themselves.

A CLIL approach to study has a "dual focus" (Coyle, Hood \& Marsh, 2010, p. 1) on both language and content goals and can assume a 'hard' or 'soft' in nature, ranging from total content immersion for students whose first language is not the language of instruction, to language-focused lessons with minimum input related to the students' content studies (Met, 2009). Studying content in a foreign language is reported as having cognitive (Lamfuss-Schenk, 2002) and motivational benefits for students (Lasagabaster, 2011; Edsall \& Saito, 2012), assuming teachers are sensitive to issues of language acquisition and knowledgeable of the content. However, this dual focus raises issues of teacher identity and the CLIL lesson's positioning on the curriculum. Lucietto (2008) and Wolff (2007) advise CLIL practitioners to clearly indicate to students the class foci and, importantly, how they are to be assessed - according to language or content competencies.

Unlike standard language or content classes, the engagement with content alongside language in CLIL classes creates an "intentional organic" (Ikeda, 2012, p. 12) in the teaching/learning process which is related to the kinds of tasks set. In this regard, Pinner (2013) argues CLIL has an "authenticity" in its tasks (in and out of class), seen by Coyle et al. (2010, p. 5) as an "authenticity of purpose". Relevant particularly to this study are Pinner's (2013) findings among Japanese university students engaged in CLIL who reportedly wanted to learn more transferable study skills, an observation which "indicates a disposition towards developing greater autonomy" (p. 53). In contrast though, in a Japanese tertiarybased CLIL study by Brown (2013), doubts about student self- monitoring and its benefit for autonomy are raised. Also, in UK-based research into study skills 
learned in content-focused language instruction by Ottewill and Drew (2003, p. 181), students were reluctant to apply them to their content studies as they perceived them as "separate and distinct." Issues surrounding study skills in CLIL contexts, or language contexts where it is hoped they will be transferred across to content studies, remain unclear.

For the context of this study, portfolio use is argued as representing a means to develop learner autonomy. Traditionally, portfolios take the form of a collection of student work which, according to Paulson, Paulson and Meyer (1991, p. 60), "exhibit the student's efforts, progress, and achievements", in that they show both the process (drafts, homework) and the product (final reports) of student work over time. They can be teacher- or student-directed in terms of content and can embrace teacher and student evaluation. If compared to evaluation of tests or homework tasks, they have the potential of exhibiting a wider range of skills (drafting, planning), particularly for non-Anglophone scholars, not shown or assessed in formal testing (Reutten, 1994). As a studentcentered tool of study, they would seem to offer an ideal means to nurture the student-directed learning and self-management skills inherent in autonomy. Indeed, Poisel (2008) promote portfolio use in CLIL as a means towards autonomy development, yet issues remain unaddressed as to how self-monitoring of progress can take place with the combination of both content and language components. If seen as a purely language portfolio, criteria can be set as to how students see their language acquisition to have progressed, for example the cando statements in the Common European Framework. Study skills too can be teacher- or self-monitored for neatness, the ability to recall notes and vocabulary; however, the framework for self-monitoring of content-related knowledge remains unclear. This lack of clarity could feasibly make the portfolio more authentic to students (and content teachers who may not encourage their use) in terms of language and study skills development, than content knowledge. Additionally, as Chen (2006) argues in observing portfolio use in Taiwanese schools, the dominance of formal examinations as the most recognized form of assessment can make portfolio use meaningless unless they are formally assessed by teachers. As student self-monitoring of progress is seen as a focus of portfolio maintenance, students fresh out of an examination-driven secondary education may be unfamiliar with the self-monitoring and management responsibilities inherent in portfolio use. 
Of final consideration in this review is the concept of "literacy networks" (Lillis \& Curry, 2010, p. 65) which highlight for scholars the importance of exploiting their social networks to develop literacy (Wellman \& Berkowitz, 1988). Fundamentally, through a shift from a pure focus on the text as a final model of academic writing to awareness-raising of accessing advice and resources from other sources apart from the course teacher, Lea and Street (1998) and Turner (2012, p.19) note that academic literacy becomes as matter of "social practice" rather than a "textual phenomenon." In practice, this encourages students, as Lillis (2013, p. 112) indicates, to develop connections between people, places and materials when engaged in the process of academic writing. Those within the students' network able to advise on writing drafts are termed as "brokers" (Lillis \& Curry, 2010, p.13), either directly commenting on the writing "literacy" itself (Lillis \& Curry, 2010, p. 93), or pointing to other "network brokers" (Curry \& Lillis, 2010, p. 283). On a wider scale, this is potentially a means to counter the "off-networked" (Belcher, 2007) conditions facing non-Anglophone scholars in periphery contexts, and also to trace the way in which texts are produced (Leander \& Lovvorn, 2006).

\section{METHOD}

This study attempts to gauge the development of autonomy in a CLIL lecture class. For this purpose, a mixed methods (Cresswell, 2009) approach has been taken to gain insights into the perceptions of students about keeping portfolios and doing out-of-class work, how they prepared for their final report, how the teacher evaluated their reports over the year, and finally, the teacher evaluation of their final reports. This methodological triangulation of student and teacher perspectives on both the process and products of the course attempts to create a personal "evidence base" (Bonnet, 2012, p. 66) for this particular CLIL practice, embracing the methods of enquiry discussed in the following sections.

\section{Early \& late course questionnaires (2011-2014)}

The content of student responses $(n=440)$ to an open-ended question (Why are your lecture teachers requesting you to manage your portfolios, do extra listening and reading?) were analyzed qualitatively over a three-year period. Data (written in either Japanese or English) was categorized according to common to 
least common, yet potentially insightful, responses for which simple percentages were calculated.

\section{Student 'literacy maps' (2012) (Lillis \& Curry, 2010)}

Data from 'maps' was analyzed quantitatively from a small group of lecture students $(\mathrm{n}=35)$ who had just submitted their final written reports and were made according to frequency of common responses.

\section{Evaluation of student portfolios (2011-2014)}

Three checks of student portfolios $(n=440)$ were made by the teacher over each academic year and graded according to tidiness of notes (teacher hand-outs, homework, report drafts and inclusion of related reading). These evaluations reflected the process and products of the course work.

\section{RESULTS}

Results are presented firstly for questionnaire findings over three years, and then move on to an analysis of the small-scale study into 'literacy maps', and finally an evaluation of portfolio evaluation over three years.

\section{Questionnaires}

\section{$2011-2012(n=124)$}

In this academic year, all lectures were audio-recorded and placed on the university server so that students could re-listen to them and check their notes. In response, early and late course findings consistently showed students' awareness of importance of using files to review past lectures (35\% of responses), and re-listen to lectures (67\%). Use of SALC showed growing popularity (from $45 \%$ in the early questionnaire to $77 \%$ in the late questionnaire) as advisors guided students in homework and the second semester report. Detailed guidance about the report structure was displayed on the SALC wall and resources relevant to the report could be accessed in the center. The usefulness of SALC's role in these writing tasks was significant in most responses (82\%). Late course findings (rising to $71 \%$ from $35 \%$ in the early questionnaire) showed some increased awareness of self-management and self-evaluation of homework 
completion and extra note-taking using files, typified in the comment "We can order our knowledge."

\section{$2012-2013(n=139)$}

Early and late course findings showed growing student awareness of selfdirection in learning, i.e. portfolio management (from $34 \%$ to $74 \%$ ), re-listening of past lectures (from $28 \%$ to $45 \%$ which continued as practice in this academic year). However, some students consistently said that the purpose of autonomous learning was teacher-directed (32\% and later $41 \%)$. Significantly though, many students (from $27 \%$ to $43 \%$ in the late questionnaire) commented on the benefits of autonomy for this class and others, and as one student commented: "To improve self-management skills."

A small number (13\%) in the late questionnaire even indicated its importance in their post-university work, as seen in the following comment: "It is necessary when I become a member of society."

As in the 2011-2012 findings, SALC's role was significant in many responses due to the homework and report writing support offered by advisors, rising from $38 \%$ to $75 \%$ in the late questionnaire. Perhaps of some note here were one or two comments which complained at the difficulty to access SALC advisors as they were frequently busy with many lecture-related enquiries.

Finally, as one important element of the lecture course is its sustained focus over several weeks on set themes, a sizeable number of students (37\%) began in the later stages to appreciate the value of the portfolio in aiding them see connections between individual lectures, resulting in the following late questionnaire comments: "to easily reflect on notes for the report", "to review" or "to look over the files again." This awareness was negligible in the early questionnaire responses.

\section{$2013-2014(n=177)$}

Important in the interpretation of findings for this academic year were two changes: recorded lectures were no longer available on the university server and SALC's advisors were no longer able to give lecture guidance on written work to the same degree as in previous years. This institutional policy meant that homework and report writing advice was mostly in the teacher's hands. SALC resources relevant to homework and report writing were still accessible but one- 
to-one advice was not so readily available. This resulted in an almost total absence of the mention of SALC and mentor support in this year's responses.

In early findings a majority expressed the view that self-direction and autonomy were key reasons for portfolio management $(66 \%)$ and other nonclassroom tasks such as gaining credit for non-lecture class note-taking (72\%). As in the previous year's responses, there was an increase from early to late questionnaire responses (29\% to $48 \%$ ) in students who noted the transferability of such study skills over to content classes. Also, the awareness of self-direction in learning for the lecture class and beyond was a positive sign in the early course stage, but again some comments (rising from 13\% to 19\% later) suggested the objective was teacher-directed, echoing similar concerns in the 2012-2013 data, as in: "To allow the teacher to check our progress."

In the later findings, interestingly, some students (14\%) noted the usefulness of not only note-taking and listening skills in other classes, but also ideas and references acquired in the lecture class, indicating a potential crossfertilization of content acquired in lecture class over to the mainstream content curriculum, seen in this typical response: "To connect lecture materials to other lessons"

Again as in previous years, a written report was set for the end of the academic year so, perhaps predictably, there was a growing awareness (from $2 \%$ to $65 \%$ ) of the importance of the portfolios from the early to the late questionnaire responses to "review" or "reflect on" past lectures to aid in seeing the "connection" between lectures.

Finally, as more self-responsibility was required of students in the second semester to monitor their self-study progress in terms of scores, some (8\%) noted the "trust" given to them by the teacher. However, there were still some students (21\%) who felt that the purpose of the management of portfolios was for the teacher to check and monitor their progress.

\section{Student networks}

In the 2012-2013 academic year, teacher awareness grew of the potential of students accessing a broader network of resources and people, other than the lecture teacher and SALC mentors. At the end of that year, just after submitting their final reports, students were invited to draw a 'map' of what resources, 
classes, and people they had consulted to complete their report. An example of this is seen in Figure 1.

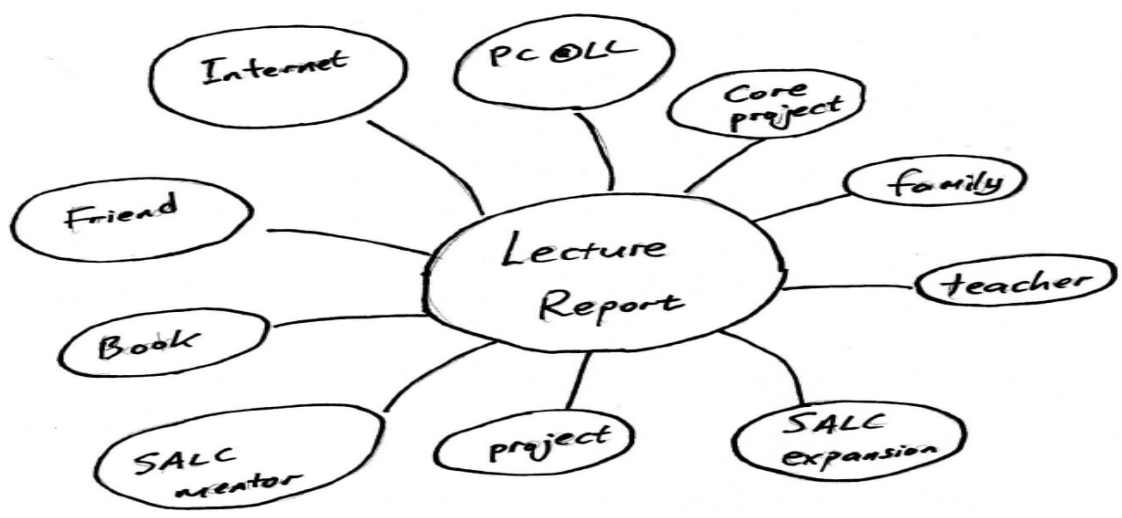

Figure 1. Student network 'map'.

Fifty-three students in two intermediate-level classes were approached to complete this task in English class time after they had submitted their final report. All were given the opportunity to decline to take part and responses were anonymous. 35 accepted, the results of which can be seen in table 1 which tabulates quantitatively in percentage terms the sources of information accessed for reports.

Table 1. Student sources of report information and advice $(\%)(n=35)$.

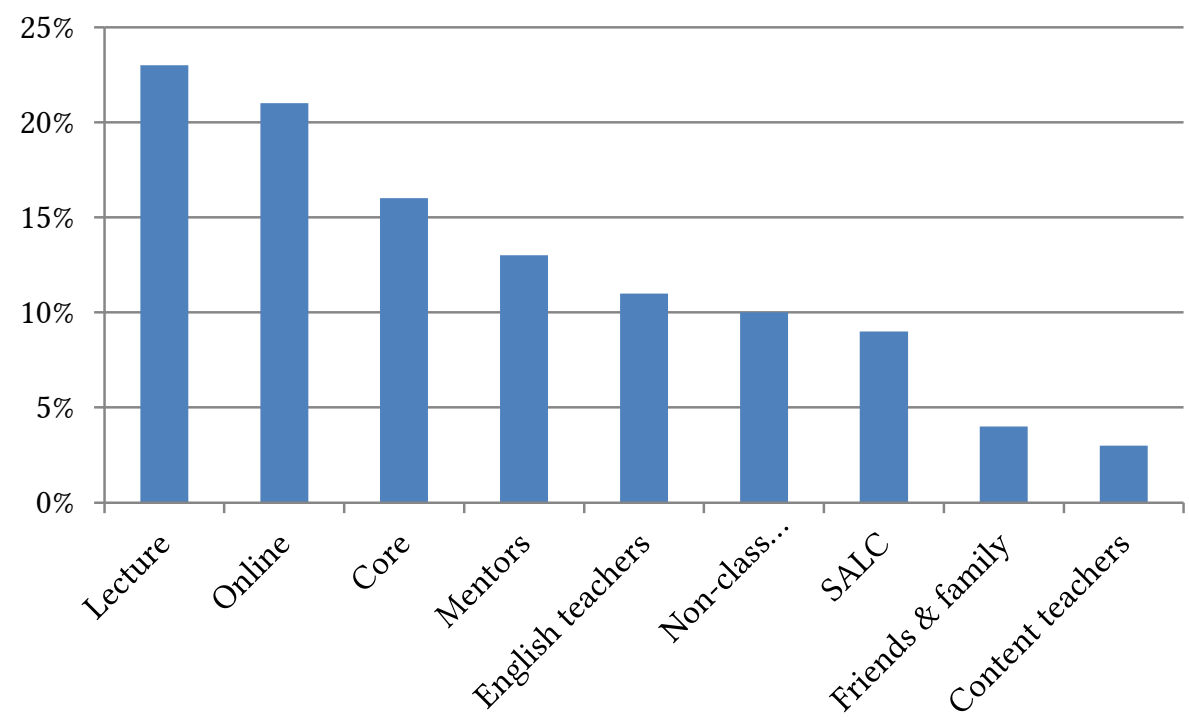


Alternatively, table 2 illustrates in detail the frequency of responses as drawn in the network maps.

Table 2. Student sources of report information and advice (frequency).

\begin{tabular}{|l|l|r|}
\hline Rank & Source of information & Frequency of response \\
\hline $\mathbf{1}$ & Lecture & 61 \\
\hline $\mathbf{2}$ & Online & 57 \\
\hline $\mathbf{3}$ & Other English classes (Core) & 41 \\
\hline $\mathbf{4}$ & SALC Mentors & 35 \\
\hline $\mathbf{5}$ & English teachers & 29 \\
\hline $\mathbf{6}$ & Non-class resources & 27 \\
\hline $\mathbf{7}$ & SALC resources & 24 \\
\hline $\mathbf{8}$ & Friends \& family & 11 \\
\hline $\mathbf{9}$ & Content teachers & 7 \\
\hline
\end{tabular}

Analyzing these small-scale findings, we can see the dependence on lecture-based materials but encouragingly, from the viewpoint of the development of autonomy, self-sourced online materials and accessing SALC mentors, SALC resources, and non-class (meaning non- university materials), and Core (the term for the other English classes on the language curriculum) were high in frequency of response. It was hoped that content teachers would be consulted as report themes were related to content curriculum themes, however, only 7 of 292 responses was disappointingly low. It would appear then that this data reveals an emerging "network" (Lillis \& Curry, 2010) of materials, resources, and brokers which aid literacy development. Brokers who provided direct guidance about the report-"literacy brokers" (Lillis \& Curry, 2010, p.93) -and resources accessed were clearly drawn in the maps; however, the "network brokers" (Curry \& Lillis, 2010, p. 283) who could not give students direct help themselves but could point them to others better able to do so were not so apparent from these maps. This shortcoming in the data could possibly be rectified in future research through more specific instruction to participants about the meaning of 'network' and 'literacy' brokering.

\section{Portfolio management}

Two checks were conducted by the teacher during the first semester and one in the second semester from 20100-2014. As the first semester focused on language and study skills, as well as lecture content themes, initial evaluation of portfolios 
revealed that students were undergoing a shift in the focus of study. Normally accustomed to pure focus on language grammar and vocabulary in Japanese secondary school, the new dual focus on both content and language was clearly taking time to adjust to. Observations of files showed that note-taking was initially performed as a near dictation activity where some students took down irrelevant notes (teacher greetings and instructional language) and took time to adjust to noting key words in lecture input. As study skills instruction in the first semester prioritized the necessary listening skills and language for content lectures, second portfolio checks indicated that improvement was made in terms of taking key points only, clarity of presenting information on the page (in the form of linear or branch notes), ordering of content (through numbered headings and sub-headings) among most students, and particularly the use of abbreviations to speed up note-taking. By the second semester, perhaps due to awareness of the report set at start of the semester, portfolios started to be supplemented by readings in both Japanese and English related to each lecture theme.

Self-monitoring was also required for the self-study of vocabulary in graded texts for which students were given online access to answers and asked on trust to record their progress in their portfolios for course credit. Observation of this self-monitoring progress revealed that most students became accustomed to this system, yet it was noted that some showed reticence to record their final grade for credit as requested. In personal exchanges with such students, some expressed the view that grading was normally a teacher's responsibility, a view which reflected their inexperience and unfamiliarity with the self-monitoring associated self-management in portfolio maintenance.

\section{DISCUSSION}

The findings from three-year study into perceptions of autonomy, portfolio use and network awareness among these Japanese university students engaged in CLIL lectures mirrors and contradicts the literature in various ways. Firstly, the importance of study skills (such as note-taking and listening skills) generally appears to grow over the first academic year with signs of possible crossfertilization over to other university courses. This would seem to contradict findings by Ottewill and Drew (2003) which bemoan the reticence to transfer skills learned on language courses over to the content curriculum. This is possibly a result of the CLIL nature of the lecture class and concurs with Pinner's 
(2013) findings, also among Japanese university students. Further to this skills transfer, questionnaire findings suggest that content from lecture is also transferred to content curriculum, an unexpected consequence of CLIL. It could be argued that this transferability of content is a result of the "authenticity of purpose" (Coyle et al, 2010, p.5) in the lecture class objectives as its content is intentionally geared towards content curriculum.

On a less encouraging note, though, is that the withdrawal SALC mentoring in the last year of data collection is evident in the absence of any mention of mentor support. This is in contrast to previous years' questionnaire and 'literacy maps' findings where SALC language advice appeared to be more prominent. In terms of the development of autonomous networking skills, this may a detrimental move in encouraging a shift away from teacher-centredness. Fundamentally, the "pedagogical dialogue" (Little, 2000, p. 3) is limited through the removal of "brokering" (Lillis \& Curry, 2010, p. 13) by mentors. Additionally, the nature of teacher-led advice differs from mentor advice as time pressures for the teacher typically result in corrective feedback, rather than the autonomybuilding guidance offered by mentors (Mozzon-McPherson, 2011).

In terms of the purpose of portfolio management, findings indicate that it is mostly recognized as a beneficial and transferable skill among students, but some issues remain worrying for the development of autonomy. Some students still viewed portfolio maintenance as for the teacher's ease of evaluation, and others showed reticence in self-grading. These issues mirror the concerns expressed by Brown (2013) and possibly, on reflection, point to a lack of instructional clarity in CLIL purposes (Lucietto, 2008; Wolff, 2007).

Of final note, the limited data emanating from 'network maps' does clearly illustrate the key role still played by the lecture teacher and lecture materials in compiling the final written report. There are, however, signs within that same data set that a wider network of brokers and materials is emerging, an indication perhaps of the propensity of Asian students towards "autonomous interdependence (Benson et al, 2003, p. 23) and recognition of collaborative modes of study (Biggs, 1994).

\section{Conclusions and implications for practice}

This study has investigated the role of portfolios and awareness of networking in the development of autonomy in a CLIL lecture preparation class. Questionnaire 
findings over a three-year period have revealed important insights for the local practice of the lecture class itself and potentially for the cross-fertilization of study skills from that class over to, and between, the EMI content curriculum. The importance of self-management and self-direction in portfolio use appears to be recognized by first-year students previously unaccustomed to such a mode of study. Limited data from one year about 'literacy maps' also shows that there is increasing awareness of the practicality of accessing a wider range of literacy brokers and resources than their lecture class teacher and lecture materials. Related to this, the role of SALC mentors in this networking process was disappointingly curtailed in the final year of data collection and was notable primarily by its absence from questionnaire responses.

In terms of the literature, "reactive" autonomy (Littlewood, 1999, p 75) through portfolio use-the student-directed sense of autonomy after teacher goalsetting-is argued in this study as an under-researched area within CLIL-related research. Much research into portfolios as a means towards developing student autonomy exists within the spheres of language learning and teaching, yet the distinct CLIL nature of tertiary lessons engaging students with content brings two question to the fore: firstly, how portfolios embracing both language and content can be authentically assessed; secondly, whether language curriculum objectives of preparing students for EMI through portfolio use and networking actually mirror local content teachers' modes of study. Certainly, as the literature review indicates, English language teaching research embraces the importance of self-direction and monitoring in autonomy building, and of particular relevance to this study, self-management in portfolio use. The issue remains whether local content teachers expect, or value, those modes of study as preparation for EMI.

Limitations of this study lie in the 'literacy maps', in that data could only be gathered for a small group of intermediate-level students at the end of the 2012-2013 academic year. Further data collection across proficiency levels could be a valuable means of not simply verifying questionnaire responses, but also revealing more insights into student resources and brokers. 


\section{REFERENCES}

Adamson, J. L. \& Coulson, D. (forthcoming). Pathways towards success for novice academic writers in a CLIL setting: A study in an Asian EFL context. In AlMahrooqi, R., Roscoe, A. \& Thakur, V. S. (Eds.) Teaching Writing in EFL/ESL: A Fresh Look. Hershey, PA: IGI Global.

Benson, P. (2001). Teaching and researching Autonomy in Language Learning. London: Longman.

Benson, P., Chik, A. \& Lim, H. (2003). Becoming autonomous in an Asian context: Autonomy as a sociocultural process. In D. Palfreyman \& R. C. Smith (Eds.), Learner autonomy across cultures: Language education perspectives. (pp. 23-40), New York: Palgrave Macmillan.

Belcher, D. (2007). Seeking acceptance in an English-only research world. fournal of Second Language Writing, 16 , 1-22.

Biggs, J. (1994). What are effective schools? Lessons from East and West. Australian Educational Researcher,21(1),19-59.

Bonnet, A. (2012). Towards an Evidence base for CLIL. How to Integrate Qualitative and Quantitative as well as Process, Product and Participant Perspectives in CLIL Research. International CLIL Research fournal, 1(4), 6678. Retrieved 28th August, 2013: http://www.icrj.eu/14/article7.html

Brown, P. S. (2013). Teaching a Medical English CLIL Course with Vocabulary Learning Strategies Instruction in Japan. Asian EFL fournal 15(4), 275-304. Retrieved 26th February, 2014: http://asian-efl-journal.com/wpcontent/uploads/mgm/downloads/45155200.pdf

Chen, Y-M. (2006). EFL instruction and assessment with portfolios: A case study in Taiwan. Asian EFL fournal,8(1), 69-96. Retrieved 4th March, 2014: http://www.asian-efl-journal.com/March 06.pdf.

Clegg, J. (2003). The Lingue E Scienze Project: Some Outcomes. L'uso veicolare della lingua staniera in appredimenti non linguistic. Centro Comunitare Quaderni 6, pp. 88-107.

Coyle, D., Hood, P. \& Marsh, D. (2010). CLIL Content and Language Integrated Learning. Cambridge: Cambridge University Press.

Creswell, J. W. (2009). Research design: Qualitative, quantitative, and mixed methods approaches. Los Angeles: Sage.

Curry, M. J. \& Lillis, T. (2006). Academic research networks: Accessing resources for English-medium publishing. English for Specific Purposes, 29, 281-295. 
Edsall, D. \& Saito, Y. (2012). The Motivational benefits of Content. On Cue Journal, 6(2), 66-94.

Ikeda, M. (2012). CLIL no genri to shidouhou [The teaching principles of CLIL]. In Watanabe, Y., Ikeda, M., \& Izumi, S. (Eds.) CLIL: New challenges in foreign language education. Volume 2, (pp. 1-15). Tokyo: Sophia University Press.

Holliday, A. (2003) Social autonomy: Addressing the dangers of culturism in TESOL. In D. Palfreyman and R.C. Smith (Eds.) Learner Autonomy Across Cultures: Language Education Perspectives. (pp. 110-126). Basingstoke: Palgrave Macmillan.

Kubota, R. (2002). The author responds: (Un) Raveling racism in a nice field like TESOL. TESOL Quarterly, 36(1),84-92

Lamsfuß-Schenk, S. (2002). Geschichte und Sprache: Ist der bilinguale Geschichtsunterricht der Königsweg zum Geschichtsbewusstsein? In Breidbach, S., Bach, G. \& Wolff, D. (Eds.). Bilingualer Sachfachunterricht: Didaktik, Lehrer-Lernerforschung und Bildungspolitik zwischen Theorie und Empirie. (pp. 191-206), Frankfurt/Main: Peter Lang.

Lasagabaster, D. (2011). English achievement and student motivation in CLIL and EFL settings. Innovation in Language Learning and Teaching, 5(1), 3-18.

Lea, M. R., \& Street, B. V. (1998). Student writing in higher education: An academic literacies approach. Studies in Higher Education, 23, 157-172.

Leander, K., \& Lovvorn, J. (2006). Literacy networks: Following the circulation of texts, bodies, and objects in the schooling and online gaming of one youth. Cognition \& Instruction, 24(3), 291-340.

Lillis, T. (2013).The Sociolinguistics of Writing. Edinburgh: Edinburgh University Press.

Lillis, T. \& Curry, M. J. (2010). Academic Writing in a Global Context. London and New York: Routledge.

Little, D. (2000). We're all in it together: Exploring the interdependence of teacher and learner autonomy. Proceedings of the 7th Nordic Conference and Workshop on Autonomous Language Learning, Helsinki, September 7th, 2000. Retrieved 14th August, 2009: http://www.iatefl.org.pl/sig/al/all.html

Littlewood, W. (1999). Defining and developing autonomy in East Asian contexts. Applied Linguistics 20(1), 71-94.

Littlewood, W. (2000). Do Asian students really want to listen and obey? ELT fournal, 54(1), 31-36. 
Lucietto, S. (2008). A Model for Quality CLIL Provision. International CLIL Research Fournal, 1(1), 83-92. Retrieved April 30, 2014: http://www.icrj.eu/11/article7.html.

Met, M. (2009). Content-Based Instruction: Defining Terms, Making Decisions. NFLC Reports. Retrieved from http://www.carla.umn.edu/cobaltt/modules/principles/decisions.html

Ministry of Education, Culture, Sports, Science and Technology (MEXT). (n.d.) Project for Promotion of Global Human Resource Development. Retrieved October 2nd , 2012: http://www.mext.go.jp/english/highered/1326713.htm

Miichi, K. (2010). More colleges offer courses taught in English. The Asahi Shimbun. Retrieved from http://www.asahi.com/english/ TKY201007160463.html.

Mozzon-McPherson, M. (2001). Language advising: Towards a new discursive world. In Mozzon-McPherson, M. \& Vismans, R. (Eds.). Beyond Language Teaching towards Language Advising. (pp. 7- 22). London: Centre for Information on Language Teaching and Research.

Okano, K., \& Tsuchiya, M. (1999). Education in contemporary Japan: Inequality and diversity. Cambridge: Cambridge University Press.

Ottewill, R. \& Drew, F. (2003). It's good to talk: Reflections on the Relationship between Language and Non-language Learning. Active Learning in Higher Education, 4(2), 181-192.

Paulson, F. L., Paulson, P. R., \& Meyer, C. A. (1991). What makes a portfolio a portfolio? Educational Leadership, 48(5), 60-63.

Pinner, R. (2013). Authenticity and CLIL: Examining authenticity from an international CLIL perspective. International CLIL Research fournal, 2(1), 44-54. Retrived 26th February, 2014 from: http://www.icrj.eu/21/article4.html

Poisel, E. (2008). Assessment modes in CLIL to enhance language proficiency and interpersonal skills. VIEWZ: Vienna English Working Papers, 16(3), 43-46.

Reutten, M. K. (1994). Evaluating ESL students' performance on proficiency exams. Journal of Second Language Writing,3, 85-96.

Sinclair, B. (1997). Learner autonomy: The cross-cultural question. IATEFL Newsletter, October-November, 139, 12-13.

Wellman, B. \& Berkowitz, S.D. (1988). Social structures: a network approach. Cambridge: Cambridge University Press. 
Turner, J. (2012). Academic Literacies: Providing a space for the socio-pragmatic dynamics of EAP. Journal of English for Academic Purposes, 11, 17-25.

Wolff, D. (2007). What is CLIL? CLIL. Integriertes Fremdsprachen -und SachfachLearnen. Retrieved from http://www.goethe.de/ges/spa/dos/ifs/ en2747558.html

\section{BIODATA}

John Adamson is a professor in the Department of International Studies and Regional Development working at the University of Niigata Prefecture in Japan. He teaches EAP. He is Chief Editor of Asian EFL Journal. 